\title{
Bahtinyen Karnavalesk Bağlamında Kült Film Kavramı
}

\author{
Mehmet SARI ${ }^{1}$
}

Öz

Karnaval kuramı edebiyat dışında sanatın diğer dallarına da uygulanabilen bir kuramdır. Filmler hem metinsel olarak hem de alımlama pratikleri bakımından karnavalesk nitelikler taşıyabilmektedir. Bu çalışmada Mihail Bahtin'in karnaval kuramı çerçevesinde kült film olgusu incelenmiştir. Çalışmada karnavalesk özellikler ışığında kült film kavramının ayırıcı özellikleri ele alınmıştır. Karnaval ve karnavalesk kavramları incelenerek Bahtin'in kuramını oluşturan ana unsurlar araştırılmıştır. Karnavaleskin sinema ile olan bağı gösterildikten sonra kült film kavramı metinsel ve metin-dışı özellikleri bakımından incelenmiştir. 'Kült film'in sinema alanında alternatif bir kanon olduğu ortaya konulmuştur. Kült filmlerin anaakım sinemaya muhalif oluşu ile karnavaleskin resmî kültürü askıya alışı örtüşmektedir. Karnavalların insanları katılımcılığa sevk edişi gibi kült filmler alımlanış olarak film ile seyirci arasındaki bariyerlerin yıkılmasına olanak sağlar. Karnavallarda insanlar arasındaki dayanışmaya kült film hayranlarında rastlanabilmektedir. Sahip olduğu birtakım yapısal ve üslupsal özellikler nedeniyle kült filmler diğer filmlerden farklılaşmaktadır. Karnavalesk açıdan bu özellikler değişkenlik ve tanımsızlık, sanat ve sanat-dışı ayrımının bulanıklaşması ve ihlal yaratma olarak ortaya çıkmaktadır. Tüm bu özellikler araştırıırken belli başlı kült film örneklerinden yararlanılmış ve kült film konseptinin karnavalesk geleneğin bir örneği olduğu sonucuna ulaşılmıştır.

Anahtar Kelimeler: Bahtin, Karnavalesk, Kült Film

Atıf: Sarı, M. (2020). Bahtinyen Karnavalesk Bağlamında Kült Film Kavramı. Akdeniz Üniversitesi İletișim Fakültesi Dergisi, 33, s. 230-250

1 Arş. Gör. Dr., İstanbul Üniversitesi İletişim Fakültesi, Radyo, Televizyon ve Sinema Bölümü. E-posta: mehmetsari@gmail.com, ORCID Numarası: 0000-0001-6473-3543. 


\title{
The Notion of Cult Film within the Context of Bakhtinian Carnivalesque
}

\begin{abstract}
Carnival theory is applicable to other branches of art apart from literature. In this study, the phenomenon of cult film has been examined in the context of the carnival theory of Mikhail Bakhtin. Characteristics of the notion of cult film were discussed in consideration of carnivalesque characteristics. The concepts of carnival and carnivalesque were examined and the main elements constituting Bahtin's theory were searched. After examining the relationship between carnivalesque and cinema, the concept of cult film was researched in terms of textual and non-textual characteristics. It has been asserted that 'cult film' constitutes an alternative canon in the area of film. Cult film's opposition to the mainstream overlaps with suspending of official culture by the carnivalesque. Cult films, like carnivals leading people to participation, allow the barriers between the film and the audience to be demolished. Solidarity among people in carnivals resembles the unity of cult film fans. Cult films differ from other films due to some structural and stylistic features. From the carnivalesque perspective, these features emerge as variability and uncertainty, blurring the distinction between art and non-art, and creating a transgression. While investigating all these features, some cult film examples were used and it was concluded that the concept of cult film is an example of the carnivalesque tradition.
\end{abstract}

Keywords: Bakhtin, Carnivalesque, Cult Film

\section{Giriș}

C Kült' gündelik hayatta sıklıkla karşılaşılan bir kavramdır. Kült kitap, kült yazar, kült aktör gibi tanımlamalar neredeyse her gün muhtelif mecralarda yer bulmaktadır. 'Kült film' terimi bunların en sık kullanılanlarından birisidir ve hakkında çok farklı görüşler ortaya atılan, tartışmalı ve yoruma açık bir kavramdır. Kült film kavramı sinemada egemen anlayışın karşısında durduğuna, hem metinsel özellikleri hem de alımlama alışkanlıkları bakımından anaakım sinemaya göre farklılık gösterdiğine inanılan bir kavramdır. Bununla birlikte ticari olarak başarısızlığa uğramış büyük bütçeli yapımlardan estetik açıdan 'çöp' olarak nitelenen filmlere kadar geniş bir yelpazeyi kapsaması bu kavrama ikircikli bakılmasına neden olmaktadır. Kült filmin özellikleri olarak tanımlanan şeyler her bir kült filme ait özellikler olmayıp filmden filme farklılık gösteren çeşitli anlatı nitelik ve işleyişlerini kapsar. The Cult Film Reader editörlerine göre kült filmler "kültürü ciddiye almaktansa karnavallaştırır ve kontrolsüz, büyük bir karmaşıklığa çevirir" (Mathijs ve Mendik, 2008, s. 2). Bu nedenle kült film kavramının karnavalesk özelliklerini araştırmak önem taşımaktadır.

Rus filozof ve edebiyat kuramcısı Mihail Bahtin (Mikhail Mikhailovich Bakhtin) (18951975) karnaval geleneğinin edebiyat üzerindeki etkilerini incelemeyi amaçlamış ve böylece karnaval kuramını oluşturmuştur. Karnaval eski çağlardan beri süregelen sosyo-kültürel bir fenomendir. Bahtin sayesinde karnaval sadece edebiyat eleştirisi ala- 
nında değil, folklorik ve kültürel çalışmalar alanında önemli bir kavram hâline gelmiştir. Karnavalın etkileri edebiyattan sanata çok geniş bir alana yayılmıştır.

Çalışmanın amacı kült film kavramının Bahtin'in karnaval kuramı bağlamında karnavalesk özellikler taşıyıp taşımadığını sorgulamaktır. Kült filmi karnavalesk özellikler açısından incelemek yoluyla hem sinemada karnavaleskin farklı bir yönünü ele almak, hem de kült film kavramını anlamaya katkı sağlamak amaçlanmıştır. Çalışmanın önemi, kült film kavramının sinemanın en kayda değer kavramlarından birini oluşturması ve görece yeni bir kavram olduğu için farklı bakış açılarına intiyaç duymasından kaynaklanmaktadır. Akademik literatürde kült film kavramı üzerine pek çok çalışma yapılmış olmasına rağmen Türkçe akademik literatürde 'kült'ün sadece beşeri bilimlerdeki diğer kullanımlarını ele alan çalışmalar bulunmakta olup sinema özelinde bir çaış̧maya rastlanmamıştır. Sinemada karnavaleskin yansımaları ise yabancı literatürde birkaç çalışmada yer alsa da türleşme ve atmosfer olarak bu kuramın sinemanın belirli bir alanına odaklandığı çalışma bulunmamaktadır. Benzer şekilde Türkçe literatürde karnavalesk hakkında incelemeler felsefe, edebiyat ve sosyoloji alanlarında yoğunlaşmaktadır. Çalışmada karnavallaşma sorunsalı karnavalın sadece sinemada metinsel olarak etkileri değil, seyircilerin alımlama pratiklerine de uzanan etkisi de bir arada tutularak incelenmiştir. ${ }^{2}$

\section{Bahtinyen Karnavalesk}

Mihail Bahtin sayesinde sadece edebiyat eleştirisi alanında değil, folklorik ve kültürel çalışmalar alanlarında önemli bir kavram hâline gelen karnaval sosyo-kültürel bir fenomendir. Orta Çağ şenliklerinin kendine has özelliklerinden hareketle geliştirdiği karnavalda "resmi kültüre karşıt olarak konumlanan bir halk kültürünün, kahkahayı, doğanın ve kolektif yaşamın ritimlerini, bedenin direncini ve işlevlerini, dile ve edebiyata taşıması söz konusudur" (Irzık, 2001, s. 23).

Bahtin'in vurguladığı anlamda karnaval, "resmi bayramın aksine, egemen hakikatten ve kurulu düzenden geçici bir özgürleşmeyi kutlardı; tüm hiyerarşik rütbelerin, ayrıcalıkların, normların ve yasakların askıya alınışının altını çizerdi” (Bahtin, 2005, s. 99). Karnavallar canlı kutlama atmosferinin yaşandığı, kültürel değerlerin tersyüz edildiği, halkı 'yönetmek' için yeni kişilerin atandığı, edepli davranışların ve adabımuaşeret kurallarının hüküm süren 'karnaval ruhu' adına geçici olarak askıya alındığı belirli periyotları ifade eder. Benzer bir ruh edebî bir esere nüfuz ettiğinde ise karnavalesk olduğu veya karnavaleski andırdığından söz edilir (Danow, 1995, s. 3).

Bahtin karnavalı tanımlarken karnavalın egemen addedilen güçlerin ve ideolojilerin engellemeye çalıştığı dinamikleri gün ışığına çıkardığını ve hayatın ve kültürün potansiyel gücünü dışa vurduğunu söyler. Karnavalı öncelikle topluluk ve katılım ile ilişkilendirir; karnavalın bireyi değil tüm insanları eksene aldığını belirterek insanların birbirleriyle samimi ve köklü ilişkiler oluşturmasını ve yaşam sevinçlerini harekete geçirdiğini

2 Karnaval ve karnavaleskin Bahtin tarafından belirli bir toplumsal pratik ve spesifik edebi eserler kastedilerek oluşturulduğu akılda tutulmalıdır. Dolayısıyla bu kavramların uyarlanışı 'bağlamından koparmak' riskini beraberinde getirir. Çalışmada bu husus göz önünde bulundurulmuştur. 
belirtir. Karnavala katılan insanlar bir bütünlük teşkil ederek sosyo-ekonomik ve politik bir örgütlenme meydana getirirler. Bahtin'e göre $(2005$, s. 36) "normalde kast, mülkiyet, meslek ve yaş bariyerleriyle birbirinden ayrılan insanlar arasında, karnaval zamanı kent meydanında bu etkinliğe has özgür ve dostane bir ilişki biçimi egemen olurdu." Böylece karnaval toplum yaşamında merkezî ve sembolik bir rol oynardı.

Bahtin karnavalı resmî törenlerden ayrı tuttuğu gibi karnavallar ile teatral eylemler arasına bir çizgi çeker. Karnaval sanat ile yaşam arasında yer alır. Aktörler ve seyirciler arasındaki bariyerlerin ortadan kalktığı karnaval "insanlar tarafından seyredilen bir gösteri değildir; insanlar onun içinde yaşarlar, herkes ona katılır, zira karnaval fikrinin kendisi bütün insanları kucaklar" (Bahtin, 2005, ss. 33-34). Resmî, feodal, politik törenlerin aksine insanlara resmiyet dışı bir dünya deneyimi sunar. Yaşamla sanat arasında yer aldığı için insanlar gerçek ile ideal olanı aynı anda deneyimlerler, bu sayede karnaval halk için ikinci yaşam olarak alımlanır. İnsanlar karnaval yasalarının yürürlükte olduğu süre boyunca karnavalesk bir yaşam sürerler. Bu yaşam bir ölçüde 'ters yüz edilmiş bir yaşam'dır ve karnavalesk olmayan yaşamın yapısı ve düzenini belirleyen yasalar, yasaklar ve kısıtlamalar karnaval boyunca askıya alınır. Aynı şekilde insanlar arasındaki çeşitli farklııılar, eşitsizlikler ve mesafeler askıya alınır ve özel bir karnaval kategorisi devreye girer: "insanlar arasında özgür ve içli dışlı, teklifsiz, samimi, sıcak bir temas" (Bahtin, 2001, s. 10). Bahtin karnaval kuramıyla halkın muhalefet duygusuna vurgu yapar ve karnavala direnişçi bir rol atfeder. Rabelais'nin eserlerini Orta Çağ karnavalı bağlamında ele alarak, otoriteyi alaşağı eden, resmî fikir, pratik ve standartlarla dalga geçen ve önceden beri süregelen halk geleneğinin varlığını kanıtlamaya çalışır. Sembolleri geçerli olan hakikat ve otoritelerin aslında göreceli olduğu hissine sahip karnaval dilinin özgün mantığını Bahtin şöyle açıklar (2005, s. 37): "Bir 'tersyüz' olma (à l'envers) mantığı, sürekli bir 'ters yöne dönme,' sürekli bir yukarıdan aşağıya, önden arkaya kayma hali, sayısız parodiler, gülünçleştiren taklitler [travesty], hakaretler, zındıklıklar, komik taç giyme, tacı geri alma törenleri."

Bahtin'e göre karnaval toplumun genel yapısını ortaya koymakta önemli bir unsur teşkil eder. Karnaval sayesinde halkın karakteristik özellikleri, sınıf farklılıkları, beğeni kültürleri, egemen kültürün halk üzerindeki etkileri rahatlıkla görülebilir hâle gelir. Orta Çağ karnavalından gelen folk mizah kültürü Bahtin'in kuramının temelini oluşturur.

Bahtin karnavala özgü olan gülme ile özgürlük ve direniş duygularının geçici olduğunu söyler. Bayramlarla bağlantılı olan özgür gülme belli ölçüde bayram günlerine ayrılmış zamanla sınırlıydı (Bahtin, 2001, s. 109). İnsanların üzerindeki baskıların azaldığı karnaval eğlenceleri resmî görüşleri ihlal eder ve toplumun kurallarını sekteye uğratır. İnsanları kontrol eden yasalar veya kısıtlamalar karnaval zamanı boyunca askıya alınır. Geçerli sistem ve hiyerarşiler geçici bir süreliğine ortadan kalkar, eylem ve etkinlikler hiyerarşik olmayan bir düzleme çekilir. Bunların gerçekleşmesi için yaratılan karnaval zamanı insanları farklı bir boyuta sürükler.

17. yüzyıldan itibaren gittikçe zayıflayan folk-karnaval yaşamı komünal gösteri anlayışını yitirmiş ve karmaşıklığını kaybetmiştir. Karnavala özgü dünya anlayışının değerinin ve niteliğinin kaybolmasıyla karnaval "kamuya açık meydanda ortaklaşa bir icraat olma" şeklindeki otantik anlamını yitirmiştir (Bahtin, 2001, s. 250). Bahtin karnavalın 
yerini karnavallaşmış edebiyatın etkisine terk ettiğini ve karnavallaşmanın doğrudan kaynağı olmaktan neredeyse çıktığını, böylelikle karnavallaşmanın tümüyle "edebi-türsel bir gelenek" hâlini aldığını vurgular (Bahtin, 2020, s. 196).

Bahtin, Rabelais'nin yapıtlarında sosyal bir oluşum olan karnavala ek olarak edebî bir biçim olan grotesk gerçekçiliği ortaya koyar. Rabelais yapıtlarında bedensel imgelerin bolluğu söz konusudur ve Bahtin bunların Orta Çağ'a dair 'skatolojik' (müstehcen, çok kaba söz/yazı) unsurlar olmanın ötesinde dikkatlice yazılıp çizilmiş toplumsal eleştiri ve yorumlar olduğunu savunur. Karnavaleskin bir kategorisi olan grotesk, karnaval zamanı dışında bastırılmış gerçeklikleri su yüzüne çıkarır. Karnaval yoluyla yaşamın düzeni altüst edilir ve bastırılmış eğilimlerin hâkimiyet sağlamasıyla otoriter düzenle dalga geçilir. Grotesk, hiyerarşilerin, egemen değerlerin ve geçerli sistemlerin olmadığı, yaşamın koşulları eşitlendiğinde ortaya çıkar. Toplumsal bir olgu olan karnavalın edebiyata (ve diğer sanat dallarına) taşınması grotesk gerçekçilik sayesinde olur.

Bahtin karnaval kavramı ile toplumsal olduğu kadar yazınsal düzlemde de egemen düzene karşı koyulduğunu, normlar ve yasakların askıya alındığını ve onlarla alay edildiğini belirtir. Yazınsal biçim ve türlerdeki karnaval motiflerinin incelenmesi yoluyla karşı duruşlar, alay etmeler su yüzüne çıkarılır. Bahtin'in karnavalına günümüzdeki karnavallarda rastlanmasa da karnavalesk ruhu başta sanat olmak üzere insanların etkinliklerinde kendine yer bulmaktadır. Çünkü insanın kısıtlamaları aşma ve kuralları sorgulama isteğine gem vurulamaz. Yani karnavala her dönemde ve her toplumda intiyaç duyulur.

\section{Tabu Karșitı Metinler ve Sinemada Karnavalesk}

Bahtin'in temelde incelediği şey karnavallaşma sorunu, yani karnavalın edebiyat ve edebî tür üzerindeki belirleyici etkisidir. Karnavalın kendisi edebî bir olgu değildir ancak kullandığı somut biçimde bedensel zevkler çağrıştıran, sembolik biçimlerle örülmüş olan dil edebiyatın diline aktarılabilir. Karnavalın edebiyatın diline bu aktarımı, "edebiyatın karnavallaşması" olarak adlandırılır (Bahtin, 2001, s. 238).

Edebiyatın karnaval ruhunu yansıtma konusunu Danow (1995, s. 4), "karnavalesk karnavalın bir aynası gibidir, sözel sanatın çok perspektifli prizmasıyla karnavalı doğrudan veya kırarak yansıtır" diye vurgular. Karnavalesk, desteklenmesi mümkün görünmeyen şeyleri destekleyen, sugötürmez görünen şeyleri alaşağı eden, doğaüstü olanı kimi zaman doğal addeden, kurmacayı gerçek gibi ele alan, sıra dışı olanı sıradan kılabilen bir kavramdır (Danow, 1995, s. 3).

Karnavalesk metinler statükoya meydan okudukları ve egemen değerler ve beğenilere karşı saldırgan oldukları için genellikle alay ve kötülemeye maruz kalırlar. Karnavalesk bakış açısından değerlendirmeler yapmak ve anaakım değerler sisteminin karşısında yer almak yoluyla bu tür metinler unutulmaya meyilli, herhangi bir popüler kültür ürünü olmaktan kurtulurlar.

Insanlar günümüzde gerçek karnaval deneyimi yaşama şansını yitirmişlerdir. Ancak Bahtin'in de belirttiği gibi (2005, s. 61) "popüler şenlikli karnaval ilkesi tamamen yok 
edilemez. İstediği kadar daraltılmış, zayıflatılmış olsun, bugün bile hayatın ve kültürün çeşitli alanlarına can katmaya devam ediyor." Televizyon ve sinema bunun en önemli araçlarındandır. Karnavala özgü özgürlüğün ve etkilerinin daha ağırbaşlı ve seyreltilmiş karnavalesk medya ile yer değiştirdiği söylenebilir.

Gerçek hayatta karnavala politik sınırlamalar getirilebilse de, sanat dâhilindeki karnavalesk unsurlarda bunlara rastlanmamaktadır. Doğrudan ya da dolaylı yollardan karnaval kültüründen izler taşıyan metinler yoluyla sanat karnavallaşır. Bahtin, toplumsal bir pratik olan karnavalın metinsel yansımalarını edebiyatta 'karnavalesk' kavramıyla ortaya koymuştur. Karnavalın esas niteliklerini vurgulamak açısından, edebiyatın yanı sıra sinema ve medyada karnavalesk ögeleri araştırmak önemlidir. Karnaval duygusunun daha geniş hâlini sürekli yeniden keşfetmek gerekir, çünkü karnaval aynı zamanda "hayal gücünün özgürlüğünü" simgeler ve "teklifsizliğin ideolojisi"dir (Hyman ve Malbert, 2000, s. 10). Bu ögeler hem edimsel hem de metinsel bağlamda araştırılabilirler.

Sinema ortamı karnavalın geçici özgürlük alanı yaratmasına benzeyen bir özellik taşımaktadır. Karnavalda hiyerarşi ve eşitsizliklerin askıya alınması gibi sinema salonunda seyirciler arasında farklılıklar silinmektedir. Tek bir amaç (film izlemek) için bir araya toplanan insanlar, sıradan hayatı sinema salonunun dışında bırakırlar ve geçici bir süreliğine de olsa özgür bir ortama girerler. Fakat karnaval sadece bu özelliği ile değerlendirilemeyecek kadar geniş bir kavramdır. Robert Stam (1992, ss. 110-111) karnavaIın etkilerinin edebiyatta olduğu gibi sinemada da görüldüğünü ve yansımalarının çok geniş bir alana yayıldığını belirtir. ${ }^{3}$ Stam sinemada karnavaleski incelerken, bu açıdan incelenmeye elverişli tüm filmleri ele almanın imkânsız ve anlamsız olduğunu söyler ve birkaç örnek ele alır. Ele aldığı filmlerin hepsinin "yıkıcı" veya "devrimci" olmadığını; bazı durumlarda karnavaleskin tamamen "oyunbaz" veya "ticarileştirilmiş" olduğunu, bazen de saldırgan ve yıkıcı olduğunu vurgular (Stam, 1992, s. 111). Örneğin İngiliz komedi ekibi Monty Python'ın filmleri Bahtin'in sözünü ettiği oyunbaz geleneğin devamı olarak görülebilir. Life of Brian (1979) ve Monty Python and the Holy Grail (1975) gibi filmler sadece edebî ve sinemasal türlerin birer parodisi değildirler, aynı zamanda Bahtinyen karnavalın da yaptığı gibi Orta Çağ'dan kalan iki kurumu, kiliseyi ve monarşiyi hicvederler. Bu filmler ekibin hayran kitlesi tarafından fanatikçe sahiplenilen kült filmlerdir. Bununla birlikte Stam'in karnavalesk yansımaların ortaya çıktığını belirttiği filmler pek çok açıdan kült film kanonuna dâhil edilebilir nitelikler sergilemektedirler.

\section{Sinemada Alternatif Bir Kanon: Kült Film}

Kült terimi sinema özelinde 1920’lerde dile getirilse de ‘kült film' kavramı 1970’lerde

\footnotetext{
3 Stam (1992, ss. 110-111) bu yansımaları on ana başlık altında toplar: "Gerçek anlamıyla çağdaş karnavalı açıkça tema hâline getiren filmler, karnavala tarihsel bir fenomen olarak yaklaşan filmler, karnavalesk veya Menippea türü edebi metinlerin uyarlandığı filmler, kurumsal hiyerarşileri altüst etmek için mizahı kullanan veya ataerkil otoriteyi yıpratmaya yönelik kahkahayı kullanan filmler, 'bedensel alt bölge'yi görsel veya sözlü olarak gülünç bir biçimde öne çıkaran filmler, biçimsel uyum ve beğeniye dayana klasik estetiği saldırganca baş aşağı eden filmler, toplumsal ters yüz etmeleri öven filmler, yüksek sanatın ve türlerin parodisini yapan filmler, tamamen biçimsel açıdan karnavallaştırma yapan filmler ve son olarak seyirci ile görüntü arasındaki bariyerleri yıkmaya çabalayan filmler veya filmle ilgili deneyimler."
} 
rağbet görmeye başlamıştır. Amerikan üniversite öğrencilerinin ucuz, yeraltı filmlerini özel gösterimlerle sunmaları kampüslerin dışına yayılarak geceyarısı gösterimlerine dönüşmüş ve anaakım vizyon programlarına alternatifler oluşmuştur.

Modern anlamda kült, bir grup insanın sanat, müzik, edebiyat veya moda gibi çeşitli dallarda, bir kişi, fikir, nesne, akım veya çalışmaya olan bağlılıklarını ifade eder. Genellikle kitaplar, filmler, televizyon dizileri ya da sanatçılar için kült ifadesi kullanılmaktadır. Bir şeyin kült hâline gelmesi için öncelikle hayran (fan) kitlesine sahip olması gerekmektedir. Bu hayran kitlesi kült hâline getirdiği şeye karşı sonsuz bir bağlılık içindedir. Bireysel kült diye bir kavram yoktur, bir şeyin kült olabilmesi için belli miktarda takipçisi olması gerekir. Çizgi roman, bilgisayar oyunu gibi eserlerin yanı sıra müzik grupları, yiyecek ve içecek markaları da kült olabilmektedir. Hayran kitleleri kült nesne ya da kişiler hakkında sürekli fikir alışverişinde bulunurlar veya periyodik aralıklarla buluşup toplantılar düzenlerler.

Hayranlar genellikle kült ilan ettikleri kişi, nesne ve eserler yoluyla kendilerini diğer insanlardan 'farklı' olarak tanımlama gayesindedirler. "Kült pratikleri, ...kentli orta sınıf gençliğinin yabancılaşmış kesimlerinin intiyaçlarını karşılamaktadır” (Marshall, 1999, s. 441). Bu kesimden insanlar kendilerini toplumun dışında konumlandırmaya meyillidirler. Kült film takipçileri kültürel hayatın vazgeçilmez aktörlerindendir. Hayran kitlesine sahip kült eser ya da kişiler genellikle anaakım dışındadır ve geniş kitlelere hitap etmezler. Ancak anaakım dâhilinde olan popüler eser veya kişiler de fanatik hayran kitlelerine sahip olabilmekte ve külte dönüşebilmektedirler.

'Kült film'in kesin bir tanımını yapmak ve bu kategoriye dâhil olan filmleri detaylıca tarif etmek zordur. Plan 9 From Outer Space (1959) gibi bir B-tipi film, Citizen Kane (1941) gibi klasik addedilen veya Star Wars serisi gibi anaakım sinemaya dâhil olan filmler farklı nedenlerden ötürü kült film olarak görülmektedirler. Örneğin kült film denildiğinde akla ilk gelen filmlerden birisi olan Casablanca'yı (1942) kült yapan "tekrar tekrar görülmek istenen bir film olması," "unutulmaz repliklere sahip olması," "çevrenizdekiler ve sizin için özel bir anlamı olması" gibi özellikleridir. (French ve French, 1999, s. 8). Bununla beraber Karl ve Philip French Casablanca'nın diğer birçok kült filmin paylaştığı sansür, kötü eleştiri, yapımcı etkisi gibi özelliklerden yoksun olduğunu belirtir. Makul sayıdaki kült filmin farklı kombinasyonlardaki "rahatsız edici, sapkın, müphem, absürt, son derece kusurlu, gülünç, akıl almaz diyaloglarla dolu ya da hayli düşük bütçeli” gibi karakteristik özellikleri Casablanca'da bulunmamaktadır (French ve French, 1999, s. 8).

Sinemada kült kavramı farklı ifadelere sahip olduğu için farklı yaklaşımlara ve bakış açılarına gerek vardır. Çünkü bazı filmler auteur yönetmenin "sembolik çalışması" oldukları, bazıları film tarihinde dönüm noktaları oldukları, bazıları teknolojik olanakları yenilikçi biçimde kullandıkları, bazıları da hâlihazırda kült bir oyuncunun filmi olduğu için kült statüsüne erişmiştir. Hatta Hills'e göre (2008) "aynı film farklı hayran topluluklarına farklı nedenlerden ötürü 'kült' olabilir."

Kült film için kısaca "canlı ve etkin bir takipçi kitlesine sahip olan filmdir," tanımı yapılabilir (Mathijs ve Mendik, 2008, s. 11). Kült filmler için öncelikle önemli olan "kendi hayran kitlesini kazanması, aradan yıllar geçse bile aynı kitle tarafından fanatikçe el 
üstünde tutulması"dır (Ertan, 2007, s. 4). Ernest Mathijs (2008) "Herhangi bir film kült film olarak doğmaz" der ve mezhep şeklindeki alımlanışın önemini vurgular, zira bu yüzden 'kült' teriminin kullanıldığını belirtir. Bu tanımlar bir filmin kült olabilmesi için öncelikle sahip olması gereken özelliği vurgulasalar da, metinsel nitelikleri dışarıda tutmaktadırlar.

Umberto Eco (2008, ss. 67-75) Casablanca çerçevesinde seyirci-film ilişkisi üzerinden giderek kült nesne ve eserlerin doğasını açıklamaya çalışmıştır. Örneğin bir filmin külte dönüşmesi için insanların film ile yapboz gibi oynayabilmesi gerektiğini söyler. Böylece film ile bütün olarak ilişkiye geçmektense, replikleri tekrar etmek, göndermeleri yakalamak, film hakkında önemli-önemsiz detaylar paylaşmak gibi belli parçalarını kullanırlar. Ayrıca film tek bir felsefeyi içermek yerine farklı fikirleri aynı anda sergilemelidir. Yaratıcılarının kontrolü dışında gelişen, canlı bir metinsellik örneği olmalıdır. Kısacası Eco için bir filmin külte dönüşmesinde önemli olan seyirci metinle olan ve metnin diğer metinlerle kurduğu ilişkileridir.

Sinema seyircileri kült filmler için bireysel anlamda aşırı sevgi beslerler. Kült film kavramının bireysel sevginin yanında toplumsal bir boyutu da vardır. Kült film deneyimi bir anlamda seyircileri 'kıdemli üye' durumuna getirir. Kleinhans'a göre (2008) "genel olarak kült filmler geniş kitleler tarafından kabul edilen filmler kanonunun dışında kalırlar. Fakat zamanla kanon hâline gelebilirler." Genel olarak ortak bir değerler sistemine dayanması ve bir 'kült film' anlayışı yaratması açısından sinemada kült film kavramının kanon niteliğine sahip olduğu söylenebilir. Mathijs'e göre (2008) kült filmler öyle güçlü itibar elde etmişlerdir ki "bir model kanon ortaya çıkmıştır." Kült film 'resmî' sinema anlayışının karşısına yerleşen alternatif bir kanon olarak değerlendirilebilir. Kült film takipçileri filmleri yalnızca 'tüketmezler', aynı zamanda onları destekler ve savunurlar. Bu savunma şekillerinden birisi de listeler hazırlamaktır. Sanatsal kriterlerin genellikle hâkim olmadığı, 'en iyi 100 kült film', 'en kanlı filmler' gibi listeler alternatif bir kült film kanonu oluştuğunun göstergesidirler.

Seyircinin filmle olan ilişkisi filmin kült anlamının en önemli ögesidir. Bu ilişki alışılagelmiş film izleme deneyiminden çok daha içli dışlı bir ilişkidir. Gösterim, dağıtım ve alımlama kült film kavramının vazgeçilmez unsurlarıdır. Çünkü kült film sadece metinlerle değil, seyircilerin filmlere olan bağlılığıyla da ilgilidir. Seyirciler 'makul' mantığını kıran ve ihlal eden eserleri benimser ve onlara bağlanırlar. Bu ihlal "zaman, gelenek, biçim ve beğeni”nin sınırlarını ihlal etmek anlamındadır (Telotte, 1991, s. 6).

Kült kategorisi esasında kapitalist sistemin tüketici kültürüne karşı bir direniş olarak doğmuştur. Kült hayranları sıradan birer tüketici olmayı reddettiklerini savunurlar. Anaakım sinema seyircisi olmak onlara göre pasif bir davranıştır ve tüketici kültürünün feminen olduğunu düşünürler. Oysa, nihayetinde kült filmler de para karşılığı çeşitli formatlarda elde edilen ve izlenen 'meta'lardır. Bu sebeple sinemada kült kategorisi muhalif kültürün paketlenip satılması olarak görülme tehlikesini beraberinde taşır. Ancak metinsel ve metin-dışı özellikleri bakımından genel film tüketim, alımlanış ve anlayışının dışında duran 'kült film'in ayrıksı bir yapıya sahip olduğu inkâr edilemez. Kült film kavramının karnavalesk özellikler açısından incelenmesinin amaçlarından biri bu yapının anlaşılmasına katkı sağlamaktır. 


\section{Karnavalesk Nitelikleri Açısından Kült Film}

Kült filmlerin sinemayı karnavallaştırdığı görüşünden yola çıkılarak, anaakım karşıtlığı, seyircilerin aktif birer katılımcılık sergilemesi, filmler sayesinde ortaya çıkan topluluk duygusu ve filmlerin bireylerde bıraktığı etkiler, kült filmlere özgü zaman duygusu ile diğer yapısal ve üslupsal özellikler ayrı ayrı incelenmiştir. Bu özellikler incelenirken akademisyenlerin görüşleri temel alınarak önemli kült film örneklerinden yararlanılmıştır.

\subsection{Otoriteden Kac̦ıș, Anaakıma Karșitlık}

Bahtin'in kuramlaştırdığı anlamda karnavaleskin sinema ve televizyon gibi mecralarda muhtelif yansımalarına rastlamak mümkündür. Jean Luc Godard'ın bazı filmleri, South Park gibi animasyon TV dizileri veya düşük bütçeli B-tipi filmler gibi karnavaleskin çok geniş bir yelpazeye yayıldığı söylenebilir.

Bahtin (2005, s. 36) açısından karnaval "resmi bayramın aksine, egemen hakikatten ve kurulu düzenden geçici bir özgürleşmeyi kutlardı; tüm hiyerarşik rütbelerin, ayrıcalıkların, normların ve yasakların askıya alınışının altını çizerdi." Resmî kültür "bünyesinde yukarı ile aşağının asla birbirine karışmadığı sarsılmaz ve değişmez bir hiyerarşi ilkesine dayanır," ve karnavalesk dünya algısı "sadece gayri resmi kültürde ifade edilebilir" (Bahtin, 2005, s. 192). Kült filmlerin metinsel bağlamda ve seyir deneyimi açısından karnavalesk özellikler taşıyıp taşımadığı ve böylesine bir geçici özgürlük alanı yaratıp yaratmadığı Bahtin'in görüşleri çerçevesinde incelenebilir.

Stam'in (1992, s. 95) vurguladığı üzere karnaval, bir parti ya da festivalden çok daha fazlasıdır, baskı görenlerin sahip olduğu muhalif kültürdür ve kültürel üretimin ve tutkunun ürettiği bir karşı modeldir. Davranış kurallarını bozguna uğratma anlamının yanı sıra baskıcı toplumsal yapıların sembolik yıkımı anlamında dünyanın aşağıdan görünümünü sunar. Bu bağlamda değerlendirilebilecek olan kült film kavramı anaakım (mainstream) sinemaya ve konvansiyonel anlatıma muhalif olarak konumlandırılır. Kült film hayranları kendilerini 'normal' sinema seyircilerinden farklı hissederler. Karnavalın karşıtlığının merkezinde kilise, otorite, kral vb. gibi kurumlar olduğu gibi kült film kavramında da anaakım merkez bir konumdadır. David Church (2008) bu farklılık duygusunun genellikle kitlesel tüketime, sanatsal elitizme ve politik doğruculuğa bir karşı koymayı yansıttığını belirtir. Mathijs ve Mendik (2008, s. 4) ise hayran gruplarının "normal ve sıkıcı" sinemaya karşıt olarak gördükleri filmleri yüceltirler. Kendilerinin ürettiği yayın organlarında vizyon filmlerine karşı neredeyse düşmanlık derecesinde olumsuz yargılar bulunmaktadır. Bu yayın organları kültü, tür sinemasındaki "sıkıcılık ve tekrarlanma"ya karşı bir direniş konsepti olarak kullanmaya başlamıştır (Mathijs ve Mendik, 2008, s. 20). Sinema seyircileri gişe filmlerine rağbet gösterdikçe kült film takipçileri kıyıda köşede kalmış filmleri göklere çıkarmaya çalışırlar.

Anaakım sinemanın varlığı kült film hayranlarının farklılık duygusuna sahip olmaları için gereklidir. Hayranlar hem kendilerine hem de ilişkiye girdikleri filmlere değer bahşetmek için karşılarına alacakları bir 'anaakım'a intiyaç duyarlar (Jancovich vd., 2003, s. 1). Birçok incelemede kült filmler anaakımın dışında konumlanır ve egemen inanç sistemleri ve dünya görüşleri ile aralarının bozuk olduğu vurgulanır. Egemen kültürel 
düzen ile arasının bozuk olması nedeniyle genellikle 'sapkın' olarak görülürler (Mathijs ve Mendik, 2008, s. 17).

Kült film, kültürel duyarlılıkların aşındıııldığı ve egemen politikalara direnen tuhaf konular ve alegorik temalar ile karakterize edilir. Beğeni, tür ve tutarlı (veya konvansiyonel) hikâye anlatımı gibi sinemanın 'kurallarını' ihlal eder. Kült filmler düzen karşıtı, Hollywood dışı ve bağımsız olarak görülür. Estetik veya tematik açıdan genellikle yeniliklere sahip olan kült filmler sisteme karşı 'şok' olma niteliği taşırlar (Mathijs ve Mendik, 2008, s. 2).

Bahtin karnavalın politik, dinsel veya edebî bakımdan resmî söylemlere karşı eleştirel bir niteliği olduğunu belirtir. Kült filmlerin böylesine bir karşı duruş sergileyip sergileyemediği tartışılmaya açıktır. Sıra dışı ve cüretkâr konulara sahip olmaları, gerçek dünyayla ilgili alegorik temaları ve kültürel duyarlılıkları bozguna uğratmalarının altında güçlü bir ideolojik bileşen bulunuyorsa filmin politik olması kaçınılmazdır. Bu bakımdan 'tehlikeli' ve 'yıkıcı' olarak görülen filmler herhangi bir altkültürel bağa sahipse külte dönüşmeye yatkın olurlar. İçerik olarak politik olmalarının yanında kült filmler genellikle "sanatta egemen olan görüşler ile anlaşmazlık içinde" görülürler (Mathijs ve Mendik, 2008, s. 18).

Karnavalesk ilkesi hiyerarşileri ortadan kaldırır ve geleneksel kural ve kısıtlamalardan bağımsız bir hayat yaratır. Marjinal ve dışlanmış olarak görülen her şey merkeze yerleşir, farklılıklar özgürlük kazanır (Stam, 1992, s. 86). Karnavaleskin bu yönü düşük bütçeli, 'değersiz' filmlerin önem kazanması ile örtüşmektedir. Düşük bütçeli filmler yapımcıların isteklerinden bağımsız oldukları gibi yapım aşamasında emir komuta zinciri işlemez ve yönetmenler genellikle tam yetkiye sahip olur. Bu özellikleri sayesinde kural ve kısıtlamalardan kurtulan filmler farklılık ve özgünlükleri yansıtırlar (Sconce, 2008, ss. 108-109). Bu duruma örnek olarak, Dünyayı Kurtaran Adam'ın (1982) Türk sinemasının görmezden gelinen filmlerinin arasından sıyrılmasına ve kült filme dönüşmesine neden olarak yönetmen Çetin İnanç'ın filmin yapım aşamasında her türlü maddi engele rağmen hayal gücünü kullanması ve yaratıcı çözümler üretmesi gösterilebilir.

Erol Mutlu (2005, s. 322) popüler kültürü Bahtin'in karnavalesk kavramı çerçevesinde ele alırken, şenliğin politik değişmeyi gerçekleştirme potansiyeline gerçekten sahip olacaksa hegemonik söylemlerle diyaloğa girmesi gerektiğini söyler. Kült film kavram olarak anaakıma ve konvansiyonel sinemaya, yani bir anlamda 'otorite'ye karşıdır. Karşısında olduğu teksesliliği, hayranları da yanına alarak yıkmaya çalışır. Ancak kült filmin anaakım ile danışıklı dövüş hâlinde olduğu söylenebilir. Örneğin Weinstock'a göre (2008) kült film ile anaakım devamlı bir diyalog içindedir. Büyük stüdyolar konvansiyonel anlatım dışındaki estetik ve tematik özellikleri kendine mal etmeye başlamışlardır, böylece insanlara 'devrim' satmaktadırlar. Kült filmler yoluyla insanlar 'farklılık' duygusu hisseder. Hiçbir şekilde kendisinden kaçılamayan, içinde yaşanan dünyayı sevmeye yardımcı olurlar (Telotte, 1991, 15). Böylece karnavala getirilen supap işlevi gördüğü eleştirisi kült filme de getirilebilir. Smith'e göre (2005, s. 267) Bahtin, "karnavalı bütün çağlar boyunca otoriteye karşı popüler bir direniş biçimi olarak savunduğu hâlde, böylesi dolaylı popüler etkinliğin sınırlı politik olanaklarını ciddi bir biçimde düşünmemiştir." Film araştırmalarında ve hayranlar arasında genellikle direnişçi bir 
rol atfedilen kült film kavramı, karnavala getirilen eleştirilere benzer bir şekilde, fazla 'ütopik' olmakla eleştirilebilir. Kült film hayranlarının 'burjuvazi' beğenisine ve maskulen düzenlemelere meydan okumak yerine daha çok onları onayladıkları iddia edilmiştir (Jancovich vd., 2003, s. 2).

Kült film hayranlığının doğuşu, sinema ekonomisine ve akademinin filmleri algılayış şekline gösterilen tepkiye ve karşı duruşa bağlanmaktadır. Oysa Jancovich (2002, s. 315) kült film hayranlığının ticari sinemanın gelişimi dışında değil, onun dâhilinde meydana geldiğini söyler. Kült film kitlesinin örgütlenmesinde sadece sanat sinemaları ve akademi sorumlu değildir, medya da geniş olarak sorumludur. Yani hayranlık rastgele oluşan yakınlık duygusundan peyda olmamıştır. ${ }^{4}$

Kült filmin kültürel tüketim politikaları hakkında açığa çıkarabileceği pek çok şey vardır. Film çalışmalarında önemli konseptlerden birisi olan ve kült film söz konusu olduğunda çelişkili ve tutarsız bir şekilde öteki olarak konumlanan anaakım sinemanın yeniden incelenmesini gerektirir (Jancovich, 2002, s. 320). Kült filmlerin anaakım sinemanın etrafını kuşatan gelenek ve beklentileri ön plana çıkardığı söylenir. Konvansiyonel anlatının sınırlarını çizer ve bu sınırları zorlarlar.

\subsection{Seyircilikten Katılımcılığa Geçiș}

Kült filmler hakkında ortak görüş, bu filmleri izleme deneyimlerinin diğer filmlere göre farklı, 'canlı' ve 'aktif' deneyimler olduğu yönündedir. Seyircilerin filmle olan etkileşiminin yanı sıra gösterim esnasında gerçekleşen birtakım aktiviteler bu görüşü desteklemektedir.

Bir filmin kült statüsü, filmin alımlanış şekline ve toplumsal konumuna bağlıdır. Filmi külte dönüştüren nihayetinde seyircilerdir. Yani kült filmler için hayran kitlesi olmazsa olmazdır. Hayran kitlesinin seyir deneyimi 'normal' seyircilere göre farklı olarak görülür. Mathijs ve Mendik (2008, s. 164) kült filmlerin kültürel etkisinin yalnızca filmi baştan sona izlemeyle değil, "deneyimlemeyle" ilgili olduğunu vurgularlar. Birçok kült filmin külte dönüşme sürecinde gösterim koşulları büyük pay sahibidir. Seyircilerin bizzat salonda yer almasının önemi, "teatral"e yakın atmosfer, gösterim esnasında yaşanan olaylar gibi başlıca özellikler gösterimin "canlılık" duygusunu artırır (2008, s. 4).

Bahtin için karnaval "aktörler ve seyirciler insanlar arasında herhangi bir ayrım kabul etmez." Sahne ışıklarının olmadığı karnaval, "insanlar tarafından seyredilen bir gösteri değildir; insanlar onun içinde yaşarlar, herkes ona katılır, zira karnaval fikrinin kendisi bütün insanları kucaklar" (Bahtin, 2005, s. 33). Benzer minvalde kült filmler, film seyrinin sıradan, geleneksel anlamına meydan okurlar. Sıklıkla film ile seyirci arasındaki bariyerlerin ortadan kalkması söz konusudur. Kült film hayranları için film izlemek, herhangi bir sinemaya gidip film izlemekten çok farklıdır. Film ile devamlı bir ilişki hâlindedirler. Seyircilerde topluluk duygusu oluşturan kült filmlerin her biri hayatın

4 Dünyayı Kurtaran Adam’ın kült filme dönüşme hikâyesi buna bir örnek teşkil eder. Gösterime girdiği tarihte seyirciden ilgi görmeyen film Boğaziçi Üniversitesi Sinema Kulübü’nün 1990'lı yıllarda gerçekleştirdiği gösterimlerle yeniden keşfedilir. Gelenekselleşen gösterimler yoluyla film kült statüsüne erişir. Ardından filmin hakları Show TV tarafından satın alınır ve televizyon gösterimleri sayesinde geniş bir kitleye ulaşır. 
sıkıcılığından 'kaçış' sağlamaktadırlar. Church (2008) kült film hayranlarının diyalogları tekrarlamak, ıvır zıvır bilgileri (trivia) paylaşmak gibi aktiviteleri gündelik hayatlarına dâhil etmelerinin, hayranların hayatlarını bir 'estetik deneyim' gibi renklendirebileceğini belirtir. Bu anlamda hayranlar kült filmler sayesinde kendi karnavallarını yaratırlar.

Kült filmler için öncelikle önemli olan "kendi hayran kitlesini kazanması, aradan yıllar geçse bile aynı kitle tarafından fanatikçe el üstünde tutulması"dır (Ertan, 2007, s. 4). Kendi başına bir film kült olamaz, mutlaka bir hayran kitlesine intiyacı vardır. Hayranlar için seyir deneyimi neredeyse filmin metinsel öneminden daha üst bir noktadadır. Filmin seyir 'ritüeli' esnasında âdeta filmin içine girerek, film ile bütünleşme yaşarlar.

Geceyarısı filmi denildiğinde akla gelen ilk örneklerden birisi kült kavramıyla âdeta özdeşleşmiş olan The Rocky Horror Picture Show'dur (1975). Film ününü yıllardır devam eden geceyarısı gösterimleriyle yakalamıştır. Hayranlar filmin gösterimi esnasında replikleri bağırarak söylemek, karakterlere tepki vermek, şemsiye açmak, dans etmek, birbirlerine su sıkmak, salona tuvalet kağıdı, patlamış mısır, pirinç gibi nesneler atmak gibi ritüellere sahiptirler. Kimi zaman da amatör oyuncular perdenin önünde sahnelere eşlik ederler (JerryLiuFilms, 2017). Stam'in (1992, s. 111) sinemada karnavalesk ögelerden bahsederken örnek verdiği gibi bu kült film, seyir deneyimi açısından "seyirci ile görüntü arasındaki bariyerleri yıkmaya" çabalar. Sinema tarihinin en kötü filmlerinden biri olarak kült hâline gelen The Room (2003) filminin gösterimleri ritüele dönüşmüştür. Hayranlar gösterim boyunca repliklere eşlik eder, sarkastik yorumlar yapar veya perdeye plastik kaşık fırlatırlar (Movie or Bust, 2018). Karnaval gülmesinin açık bir örneğine bu gösterimlerde rastlanmaktadır. Corrigan (1991, s. 29) kült filmlere özgü seyirci-film ilişkisinin "metinsel otorite"yi ve "sistemik uyum"u yok saydığını vurgular. Yani seyirciler geleneksel film seyrinde olduğu gibi normal birer seyirci değildirler, artık katılımcı durumuna gelmişlerdir. Filmi sadece seyretmekle kalmazlar, aynı zamanda 'yorumlar' ve seyri 'aksatırlar.' Bu sayede kült filmler, bilerek ya da bilmeden, standart seyir ve değerlendirme pratiklerini düzenleyen sabitlik ve edilgenliği ihlal ederler. Replik, mimik ya da filmde kullanılan bir nesne gibi imge ve ayrıntılarla özdeşleşme yaşanmaktadır. Bu nedenle filmleri normal değerlendirme stratejilerinin işe yaramadığı, devamlı 'yeniden okuma'ların gerçekleştiği Corrigan tarafından iddia edilir (1991, s. 32). Yeniden okumalar filmi neredeyse ikinci plana yerleştirir.

Teknolojik gelişmeler ve filmlerin rahat erişilebilir konuma gelmeleriyle kült film seyirleri evlerde ve daha az kişiyle yapılır duruma gelmiştir. İnternetin yaygınlaşmasıyla filmlere erişimin kolaylaşması filmlerin kült statüsüne zarar veren bir olgu olarak görülebilir. Örneğin evde tek başına, ritüelistik hareketlerinden mahrum şekilde izlenen The Rocky Horror Picture Show kült anlamını kaybetme noktasına gelir. Seyircilerin katılımcılığa terfi etmelerinin bu açıdan mümkün olmayacağı düşünülebilir. Yine de bu gibi gelişmelerin kült filmler için büyük bir handikap oluşturmayacağı savunulabilir. Church (2008) kült film takipçilerinin internet üzerinden web siteleri, kişisel bloglar gibi sanal yollarla yeniden birbirlerine bağlandıklarını söyler. Bu tür iletişim yolları basılı yayınlara nazaran karşılıklı etkileşime daha fazla izin vermektedir. Teknolojik gelişmeler sayesinde filmlere erişim şekilleri değişse de kült deneyiminin temel karakteristik özellikleri değişmemiştir. Bu deneyim hâlen daha "aktif, müşterek, isyankâr, sadık ve eklektiktir" (Mathijs, 2008). Hills'e göre (2008) kültün toplumsal alanı tamamen feshedilemez. Kült 
komüniteleri film galaları, festival veya özel gösterimlerde bir araya gelmenin yollarını arayacaklardır.

\subsection{Topluluğun İçinden Bireysel Dıșavurumlar}

Rabelais'nin pazar ve karnaval meydanıyla ilişkili olan kinizminde söz konusu olan "bir çocuğun bireysel neşesi değil, panayır yerinde bir araya gelen halkın kolektif neşesi” (Bahtin, 2005, s. 172) olduğu gibi, hayranlar ev toplantıları, sinema salonu gösterimleri veya filmler için düzenlenen festivallerde bir araya gelerek ortak bir cemaat duygusuna sahip olurlar. Hayranlar külte dönüşen filmi seyrederken filmle ve birbirleriyle iletişim hâlindedirler. Her kült film kendi topluluğunu oluşturur. Bu topluluğun üyeleri birbirlerine benzer şekilde ve düzenli olarak 'tapınma' eylemini gerçekleştirirler.

"Karnaval, insanları yaşamdaki en önemli öğe hâline getirir. İnsanlar, karnavalın katılımcıları olarak evreni cisimlendirir hâle gelir" (Lechte, 2006, s. 32). Kült film için önemli olan sadık bir hayran kitlesine sahip olmasıdır. İnsanlar ise sinemayı sevmelerinin yanında, kült olarak gördükleri filmlere diğerlerine göre ayrı bir önem gösterirler. Karnavala benzer olarak kült film insanların kendilerini ‘birey' olarak hissetmelerini sağlanmaktadır. Sinema tarihinin derinliklerine dalarak keşfettikleri her yeni film, külte dönüşme aşamasında insanları farklı deneyimlere sürükler. Bu deneyimin sinemaya gidip herhangi bir filmi izlemek deneyiminden farklı olduğuna inanılır. Bir insanın tek başına bir filmi kült ilan etmesi önemsizdir ve filme artı değer eklemez. Kült film bir insandan daha fazlasına ihtiyaç duyar, çünkü kült kimliğini kazanması belli bir grup insana bağlıdır. Bahtin için karnaval, "sıradan insanlar arasındaki dayanışmanın önemini ve onların popüler kültürünün canlılığını” (Smith, 2005, s. 267) doğruluyorsa, kült film, benzer şekilde hayranlar arasındaki cemiyet duygusunu ortaya çıkarır ve bu duyguyu besler.

Geceyarısı gösterimleri, kült filmler için düzenlenen özel festivaller veya hayran toplantılarında, şenlikli, karnavalesk bir havaya rastlamak mümkündür. Hayranlar sadece filmi izleyenlerin anlayabileceği şakalar yaparak, replikler söyleyerek kendi aralarında özel bir iletişim kurarlar. Yaratılan özgün kolektivite filmin kült statüsü için önemli bir özelliktir. Ayrıca film metin olarak hayranlara diğer seyircilere göre daha fazla anlam ifade eder. Karnaval esnasında insanların toplumsal rollerinden sıyrılabilmesi gibi, kült film hayranları filmler için düzenlenen bu tür aktivitelerde, geçici de olsa aralarındaki mesafeleri ve farklılıkları askıya alırlar. Filmdeki karakterlere benzemek için giydikleri kostümler ve yaptıkları makyajlar bu bakımdan karnavalesk bir hava yaratır. Hayranlar istedikleri karaktere bürünebilir ve filmden replikler söyleyerek diğer insanlarla özgün bir iletişime geçer.

Sexton'a göre (2008) kült filmlerin esas sosyal fonksiyonu "bireysel kimlikle bağlantılı olarak topluluk duygusunu beslemektir." Kült filmler hayranlar için kişisel olarak büyük derecede önemlidirler. Aynı zamanda bireysel olarak bu hayranlar diğer kendine benzeyen bireylerle topluluk oluşturma ilişkisi içerisine girerler. Kendilerini 'farklı' hisseden insanlar böylelikle bir topluluğa 'ait olma' duygusuna da sahip olurlar. Kült film sayesinde insanlar 'standart'ıktan ve kendilerinden sahip olması beklenilen kişiliklerden bir 
anlamda kaçma fırsatı yakalarlar.

Karnavalın yarattığı geçici özgürlük ortamı ile kült film deneyimini benzeştiğini söylemek mümkündür. Kısıtlamalardan kurtulan seyirciler yaşamın alışıldık, meşrulaşmış alanından çıkıp özgürleşme hissederler. Sorumluluklarından geçici bir süreliğine de olsa kurtulurlar. Telotte'ye göre (1991, s. 13) kült filmler toplum ve toplumun kuruluşlarınca onaylanan ve aktarılan anlamlardan farklı olan bir anlam taahhüt eder. Kendilerine bahşedilen bu anlam sayesinde gerçeklikten bir süreliğine kurtulurlar. Örneğin The Rocky Horror Picture Show hayranları favori karakterleri gibi giyindiklerinde toplum içinde sahip oldukları, normal kimliklerini askıya alırlar.

Bu açıdan 'geceyarısı filmleri' belki de kült film hayranlığıyla belki de en çok bağdaşan fenomendir (Jancovich vd., 2003, s. 3). Bu filmler öncelikle özel gösterim koşulları yüzünden diğer filmlerden farklılık göstermektedirler. Seyirciler bu filmleri yalnızca hava karardıktan sonra değil, gün değişimi yaşandığı anda, bir nevi "sihirli bir zaman"da izlerler. Filmler yalnızca geleneksel film izleme koşullarına değil, sinemasal konu ve tarzlara da meydan okurlar. Toplum açısından sakıncalı ve sapkın olarak görülen eşcinsellik, transvestizm, uyuşturucu kültürü gibi temalar geceyarısı filmlerinde kendilerine yer bulurlar (Telotte, 1991, s. 103).

\subsection{Tanım ve Ayrımları İhlal Eden Karnavalesk Kült Film}

Kült film konsept olarak sahip olduğu birtakım yapısal ve üslupsal ayrımlar sayesinde diğer film türleri ve kategorilerinden farklılaşmaktadır. Karnavalesk bağlamında ele alındıklarında bu özellikler değişkenlik ve tanımsızlık, sanat ve sanat-dışı ayrımının bulanıklaşması ve ihlal yaratma olarak ortaya çıkmaktadır.

Kült filmler genellikle yaratıcılarının farklı şeyler denemekten çekinmedikleri özgür yaratımlardır. Sanat sinemasının ciddiliğine genellikle sahip değildirler. Tek bir türe veya üsluba ait değillerdir. Üzerinde herkesin anlaştığı, kesin yargılarla ifade edilen bir kült film tanımı olmamasının en büyük nedeni budur. Bu bağlamda edebiyat tarihindeki karnavallaşmanın işlevine benzer bir düstur edinir. Bahtin'e göre (2001, s. 254) karnavallaşma Avrupa edebiyatının gelişiminde türler, biçemler ve kapalı düşünce sistemleri arasındaki engellerin yıkılmasına yardımcı olmasıdır ve böylelikle "uzak olanı yakınlaştırmış, kopuk olanı birleştirmiştir."

Kült filmlerin başlıca yapısal özellikleri arasında estetik veya tematik açıdan yenilik, estetik veya ahlaki açıdan 'kötü' duruş, iyi ve kötü arasındaki sınırın belirsizliği, türler arasında gezinti ve geçişler, popüler kültür ve diğer filmlere yapılan referanslar (metinlerarasılık), açık uçlu sonlar gibi özellikler bulunmaktadır (Mathijs ve Mendik, 2008, ss. 2-3). Bu bakımdan kült filmlerin karnavalesk dünya anlayışına birtakım genel yapısal özellikleri açısından sahip olduğunu iddia etmek mümkündür. Farklı türleri kendi bünyesinde birleştiren, sanat sineması ya da trash (çöp) film ${ }^{5}$ gibi kapalı ayrımlara itibar

5 Trash film tanımlaması çeşitli niteliklere sahip, oldukça düşük bütçeli filmleri kapsamaktadır. Eğitimli trash film hayranları bu filmleri sadece 'eğlenceli' oldukları için tercih etmez; bu filmlerin anaakım sinemadan olumlu bir yönde 'sapma' ve anaakımı ihlal etme niteliklerine sahip olduklarını düşünürler ve ironik bir yaklaşımla bu filmleri alımlarlar (Sarkhosh ve Menninghaus, 2016). 
etmeyen, üslupsal açıdan yenilik veya farklılıklar barındıran kült film, sinemanın önem taşıyan kavramlarından birisini oluşturur.

Morson ve Emerson (1990, s. 93), Bahtin'in romanı tanımlarken karnavalı tanımlayışına yakın bir yaklaşım içinde olduğunu belirtir. Bahtin favori türü olan romanı ele alırken, yazınsal tarihi, verili gerçekleri ve sabit kanonlarıyla 'tamamlanmış' ve 'sonuçlanmış' türler ile karnavaldan filizlen ve türler arasında gezinen romanın süregelen çatışması olarak ele alır. Karnavalesk tamamlanmışlığın, kapalııı̆ın, tabuların karşısında yer alır. Kült filmin genel özelliklerinden birisi de tamamlanmışlık anlayışının dışında durması, sıklıkla 'açık uçluluk' teşkil etmesidir. Mathijs'e göre (2008) kült filmin en önemli sosyal işlevi, muğlaklık, çok katılık ve eksiklik duygusu yaratmasıdır. Genel kanıya göre bir film iyi, kötü, güzel, çirkin gibi tek bir şekilde tanımlanabilir; kült hayranlarının algılayışı ise bu inancın tutarsızlıklarının altını çizer. Çünkü filmler aynı anda hem iyi hem de kötü, hem bunların hiçbiri, hem de bunların daha fazlası olabilirler. Kült filmler 'final anı'ndan yoksundurlar. Böylece insanlar tarafından sabit bakış açısıyla değerlendirilmekten kurtulurlar.

Umberto Eco (2008, s. 68) kült bir yapıtın parçalanabilir ve bozulabilir nitelik teşkil etmesi gerektiğini belirtir. Böylece alıcı yapıt ile istediği gibi ilişkiye girebilecek, yapıtı bütün olarak düşünmek yerine parçalarıyla ilgilenebilecektir. Mükemmel bir film hafızalarda merkezî bir fikir veya duygu çerçevesinde, bütün olarak yer ederken; 'dengesiz' filmler birbirinden kopuk imgeler ve anlar olarak akıllarda kalır. Eco'ya göre bir kült film tek bir fikir etrafında oluşmamalı, birçok fikri bir arada bulundurmalıdır. Uyumlu bir felsefeye veya kompozisyona sahip olmamalı, 'yetersiz' görünmelidir. Eco için Casablanca bütün olarak 'mükemmel' bir film değildir, ön plana çıkan belli motiflere ve anlara sahip olduğu için külttür.

Karnavalın grotesk gerçekçiliği geleneksel estetik anlayışın güzel-çirkin ayrımını altüst eder ve kaba ve yıkıcı olanın saklı güzelliğini ifşa eder. Karnaval estetiğinde her şey kendi zıttını içinde barındırır. Böylece iyi-kötü, güzel-çirkin, doğru-yanlış karşıtıklıklarına farklı bir perspektiften yaklaşılır. Rasyonel bakış açısının terk edilmesiyle değersiz görülen kitle sanatı ile avangart sanat karşıtığının yanlışlığı ortaya çıkar. Çünkü böyle bir ayrım hem popüler hem de eleştirel olan melez oluşumlara yer vermez, onları tanımaz (Stam, 2000, s. 156). Bahtin'in (2001, s. 258) vurguladığı şekilde karnavallaşma, "hazır mamül bir içeriğe dayatılan dışsal ve hareketsiz bir şema değildir." Böylece yeni ve daha önce görülmemiş şeylerin keşfedilmesini olanaklı kılar.

Kült filmin karnavaleskin bu özelliğini taşıdığı muhtelif özelliklerle açığa çıkar. Church (2008) kült filmlerin en değerli özelliğinin, sanat ile trash arasındaki sınırları bulanıklaştırma becerisi olduğunu belirtir. Kült film tanımlaması sıklıkla 'o kadar kötü ki, o kadar iyi' niteliğindeki filmler için kullanılır. Bu aynı zamanda kült filmin veçhelerinden biri olan, Susan Sontag'in tanımlamaya çalıştığı camp olgusunu da özetlemektedir. Aşırılık, gösterişlilik, kitsch gibi kavramları içinde barındıran camp'e göre "zevklilik sadece iyi zevk sahibi olmak değildir, zevksizliğin de bir zevki olabilir" (Sontag'dan akt. Behlil, 2001, s. 209). Camp türünde görülen eserler Bahtin'in grotesk beden kavramının araştırılmasına olanak sağlarlar. Bahtin groteski, bedene ve bedensel aşırılıklara atıfta bulunan ve bunları neşeli bir şekilde kutlayan bir konsept olarak görür; ki camp’in 
aşırılıklara yaslanan özüyle örtüşmektedir.

Neyin sanat olup neyin olmadığı tartışması bu çalışmanın sınırlarını aşmaktadır. Ancak karnavaleskin bu konudaki yaklaşımı ile kült filmin özelliklerinin örtüştüğü görülebilir. Jeffrey Sconce'un paracinema kavramı sanat ve sanat-dışılık bağlamda ele alınabilecek, kültün başka bir veçhesini oluşturur. Beğeni hiyerarşilerinin reddedildiği, anaakım dışındaki bir çok türü barındıran, bir bakıma karşı-beğeni kültürü olan paracinema, seçkin sınıfın, 'kültürel burjuvazi'nin beğeni anlayışına tepki olarak var olur. Böylece genel sinema kriterlerine göre 'kötü' olarak değerlendirilen filmler, paracinema anlayışı sayesinde estetik ve sanatsal yönden değerli görülürler. Sconce'a göre önemli olan zevk ve beğeni kavramlarıdır (Sconce, 2008, s. 109). Paracinema'nın içine giren türler genellikle egemen sanatsal değerlere göre incelenmeye değer bulunmayan alanlara dâhildirler.

Sconce, "dünyanın en kötü yönetmeni" namlı Ed Wood'u paracinema çerçevesinde ele alır. Wood'un filmleri (Plan 9 from Outer Space [1959], Glen or Glenda [1953] gibi) başta camp olarak değerlendirilse de, paracinema kavrayışıyla alay edilmekten kurtulurlar ve takdire layık görülürler. Sconce'a göre (2008, s. 114) Wood, Jean Luc Godard gibi, Hollywood'un geleneksel yapım, dağıtım ve gösterim koşulları ve kısıtlamalarının dışında kalan, eşsiz bir yetenektir. Wood'un filmlerini paracinema konseptinde değerlendirmenin anahtarı Wood hakkındaki bilgilerdir. Örneğin Glen or Glenda, kadın kıyafetleri giymekten hoşlanan sıradan bir adamın hikâyesini konu edinir. Film tarz olarak bir istismar sineması örneğidir ancak Wood'un gerçek hayatta bir travesti olduğunun bilinmesi, yani filmin dışında kalan bir bilginin edinilmesi paracinema hayranlarının filmdeki kültürel kodların karmaşıklığını bütünüyle takdir etmelerine imkân tanır. Nasıl ki Godard'ın Marksizm ile olan ilişkisine dair bilgiler yönetmenin filmlerini değerlendirmek amacıyla kullanılıyorsa, paracinema hayranları Wood'un hayatına ilişkin bilgileri, filmleriyle daha yakın bir ilişki kurmak için kullanmaktadırlar (Sconce, 2008, s. 115). Ayrıca Sconce trash filmleri izleme ve değerlendirme stratejileri ile kültürel seçkincilerin filmleri değerlendirme stratejilerinin benzeştiğini söyler. ${ }^{6}$

Bahtin'e göre Rabelais'nin uzun yıllar değerinin anlaşılamamasının nedeni eserlerinin edebiyat dışı doğasıdır. Karnaval dönüşerek ve biraz da saldırgan bir biçimde resim, tiyatro, vb. sanatın çeşitli dallarında devamını sürdürmüştür. Örneğin karnavalın bir parçası olan grotesk, dışa vurumculuk ve gerçeküstücülük gibi akımlarda yer bulmuştur. "Marjinal ve tahrip edici sanat iktidara ve resmî kültüre olan muhalifliğiyle karnaval ruhunu yeniden canlandırır" (Stam, 1992, s. 99).

Bu bağlamda, ihlal yaratan (transgressive) eserler olarak görülen kült filmlerin karnavaleskin bu özelliğine sahip olduğu incelenebilir. İhlal yaratan sanat esas olarak toplumsal tabulara karşı çıkmayı veya onları yıkmayı amaçlar. Toplumun tutucu kesimlerini ve onların bakış açılarını aşağılamak için tasarlanan, şok edici sanattır. İhlal sinemasının manifestosunu yazan Nick Zedd yapılmış şeyleri taklit etmektense statükoyu tehdit edecek şaşırtıcı işler ortaya koymayı hedefler (Zedd, 2020). Zedd mani-

6 Türkiye özelinde Dünyayı Kurtaran Adam düşünüldüğünde benzer bir dinamiğin işlediği görülecektir. Filmin itibar kazanmasına önayak olanlar sinema kültürüne sahip sinefillerdir. Zira düşük bütçeli, 'ucuz' filmlerin sahiplenilmesi bir kültürel sermaye gerektirmektedir. 
festosuyla kendisinin ve Andy Warhol, John Waters, Kenneth Anger gibi yeraltı sanatçı ve yönetmenlerinin işlerini ve tavırlarını açıklamaya çalışmıştır. Bu kişilerin sinema için ürettikleri başlıca eserler kült olarak değerlendirilmektedir.

Kült filmler ortak metinsel özellikleri bakımından genellikle tuhaf, sıra dışı, sapkın olarak nitelenirler ve biçimsel ve içeriksel açıdan meydan okudukları ve ihlal yarattıkları görülür. Telotte (1991, ss. 15-16) kült filmlerde keşfedilen şeylerin filmden filme değişiklik gösterdiğini belirtir. Keşfedilen şey ister Humphrey Bogart veya James Dean gibi belli personalara olan intiyaç, isterse Repo Man veya The Rocky Horror Picture Show gibi filmlerin yarattıkları toplumsal veya cinsel açıdan 'ihlal'lerine duyulan arzu olsun, karşılaşılan şey zamanın ve geleneklerin sınırlarını ihlal eden ve statükoya karşı duyulan memnuniyetsizlikten bahseden formlardır.

Paracinema anlayışı sanatsal sinemanın kriterlerini kullanmak yerine filmlerde 'hata' veya 'yanlışlık' olarak değerlendirilen ögeleri ön planda tutar. Sistematik olarak konvansiyonel sinema anlayışını çarpıtan yönetmenler, paracinema bağlamında sanatçılıkları yerine 'tuhaflık'larıyla değerlendirilmektedir. Filmleri sanatsal açıdan bilinçli bir şekilde Hollywood sinemasından sapmasa da, teknik koşullar ve maddi yetersizlikler nedeniyle bunu gerçekleştirmektedir. Paracinema bağlamındaki filmlerle bu sapkınlıklarından dolayı alay edilmez, tam tersine eşsiz, cüretkâr ve tamamen 'tahrip edici' olarak görülürler. Kitleler için paracinema biçim ve içerik açısından gerçek bir 'karşı-sinema' meydana getirir (Sconce, 2008, s. 111). Hayran kitleleri için film ne kadar 'kötü' ise, o kadar değerlidir.

Kült filmlerin genellikle bedene yönelmesi karnavalın bir kategorisi olan groteski devreye sokar. Grotesk bastırılmış gerçeklikleri su yüzüne çıkarmak yönünde işlemektedir. Bozulmuş, çarpıtılmış figürler ile geleneksel yapıları gözler önüne serer ve onları eleştirir. Grotesk gerçekçiliğin temel ilkesi itibarsızlaştırmaktır, "yani yüksek, ruhani, ideal, soyut olan her şeyi yukarıdan aşağıya indirmektir; yukarıdakileri maddi düzeye, çözülmez bütünlükleri içinde dünya ve bedenin alanlarına aktarmaktır" (Bahtin, 2005, s. 47). Grotesk beden dünya ile devamlı bir alışverişte bulunur ve yeme, içme, dışkılama, doğurma, cinsel birleşme gibi edimler önem kazanır. Bu edimler ile kült filmlerde sıklıkla karşılaşılır.

Tampopo (1977) filminin ana teması yemek ve cinselliktir. Mizahi yönü öne çıkan filmde ana hikâyenin etrafında gelişen pek çok yan öykü bulunmaktadır. Bu öykülerde yeme-içme ve cinsellik eylemleri ön plandadır. Yemek sahnelerinde hazza vurgu yapan uzun ve detaylı planlar, cinsellik ve yemeğin birleştiği fanteziler bulunmaktadır. Japon ve Batı kültürü ile genel olarak erkek egemen kültürün her biri farklı yönlerden ince bir dille eleştirilmektedir.

Pink Flamingos (1972) içerdiği aşırılık ve 'sapkınlık' ile sinema tarihinin en tuhaf filmlerinden biridir. Yönetmen John Waters cinsellik ve aile gibi konularda genel ahlak kurallarını alaşağı ederek seyircileri şoke etmeyi amaçlamıştır. Filmin ana karakteri, kilolu bir travesti olan Divine davranışları ve görüntüsü itibarıyla başlı başına grotesk bir figürdür.

Kült filmler genellikle aşırılık gösteren filmlerdir. Karnavalın özelliklerinden birisi olan 
alışıldık ve genel olarak kabul edilen durumların ihlal edilmesi, yaşamın alışıldık tekdüzeliğinden çekip çıkarılmasının örnekleridirler. Kült filmler ister anaakım sinemanın estetik normları olsun, ister toplumsal ve ideolojik normlar olsun her zaman ihlal yaratırlar ve bu normlara meydan okurlar. Kült film kavramının önemli olmasının en büyük sebeplerinden birisi budur.

\section{Sonuc}

Kült film kavramı sinema için oldukça önem taşıyan bir kavramdır ve neredeyse her gün sinemayla ilgili çeşitli mecralarda bu terimle karşılaşılır duruma gelinmiştir. Ancak bu 'dile pelesenk olma' durumu, kavramın içinin boşaltılması tehlikesini beraberinde getirmektedir. Sinemaseverler istedikleri anda istedikleri filme ulaşır duruma gelmişlerdir ancak kült film arayışı sonlanacak gibi görünmemektedir. Kült filmler seyircilerin sinema heyecanını ayakta tutan, seyircileri bir araya toplayıp onlara seyirden öte deneyim yaşatan, onları katılımcılığa sevk eden, sahip olduğu ayrıksı metinsel özellikleriyle öne çıkan ve beğeni kalıplarını zorlayan filmlerdir. Kült filmlerin her dönemde ilgi çekmesi kaçınılmazdır. Hollywood yapımcıları tam da bu sebeple vizyona yeni soktukları filmleri 'kült' etiketiyle pazarlayabilmektedirler. Bu nedenle kült film kavramı üzerine yapılan akademik çalışmalar önem arz eder.

Mihail Bahtin, Rabelais'nin eserlerinden yola çıkarak Orta Çağ karnaval geleneğini incelemiş, sonuç olarak sadece edebiyat eleştirisi alanında önem taşımakla kalmayan, sosyo-kültürel bir fenomen olarak karnaval kuramını oluşturmuştur. Bahtin'e göre karnavala özgü unsurlar, onun kültür açısından taşıdığı önemi ortaya koyar. Karnaval insanlar tarafından seyredilen bir gösteri değil, insanların katılım gösterdikleri ve içinde yaşadıkları bir olgudur. Karnaval tüm insanları eksene alır ve insanlar arasındaki çeşitli farklılıklar, eşitsizlikler ve mesafeler geçici olarak askıya alınır. Karnavalesk ve karnavallaşma Bahtin için edebiyatın egemen atmosfer ve türlerini, onların varsayımlarını ihlal eden ve onları özgürleştiren eserlere atfedilir. Karnavalesk terimi günümüzde popüler kültürde metaforik olarak otoriteye ve iktidara gösterilen direnci ifade etmektedir. Karnavaleskin önemi 'aşağı' kültürün 'yüksek' kültürü bir nevi istila etmesinde yatar. İktidarın keyfî kültürel sınıflandırmaların meydan okunur. Karşısına egemen güçleri koyan ve onları değiştirme, yıkma veya sarsma amacı güden kültürel girişimleri karnavalesk özellikler bakımından incelemek bu bakımdan anlamlıdır. 'Kült film'in taşıdığı nitelikler ele alındığında bu kültürel girişimlerden birisi olduğu iddia edilebilir.

Kült filmlerin sinemada egemen anlayışın karşısında durduğu ve ayrıksı metinsel ve metin-dışı özellikleriyle öneme haiz bir kavram olduğu görülmektedir. Kült filmleri değerlendirmenin kilit noktası onu hem metinsel hem de metin-dışı özelliklerini bir arada ele almaktır. Metinsel açıdan bir çekiciliği olmasının yanında hayran kitlesine sahip olan filmlere kült film demek uygundur. Kült filmler için seyircilerin rolü büyük önem taŞır, çünkü filmler kült olarak doğmazlar, onları bu statüye yerleştiren filmi fanatikçe sahiplenen kitlelerdir. Bir filmin kült olmasının altında yatan nedenler filmden filme değiştiği gibi, kült filmlerin hayran kitlelerinin profili de filmden filme farklılık arz etmektedir.

Kült filmler ve hayranları kendilerini anaakım filmlere ve onların 'normal' seyircilerine 
karşı konumlamaktadırlar. Kült film takipçileri egemen kültürel değerleri reddederler ve söz konusu filmler bu değerleri reddettiği için kült filmlere bağlanırlar. Popüler kültürün sinema alanından farklı olarak kendi kültürel çevresini yaratmış ve sürdürmektedir. Kült film kavramı sahip olduğu birtakım özgün nitelikler nedeniyle bu türden çıkarımlar yapmaya olanak tanımaktadır. Ancak her kült filmin günümüzde böylesine bir altkültürel ortam yarattığını düşünmek, gerek değişen gösterim koşulları açısından, gerekse filmden filme değişiklik gösteren nitelikler yüzünden doğru olmayacaktır.

Bu çalışmada kült filmlerin karnavalesk özelliklere sahip olduğu hipotezi öne sürülmüştür. Kült filmlerin belli başlı metinsel ve metin-dışı özellikleri, yapısal ve üslupsal ayrımları akademisyenlerin görüşleri çerçevesinde ve belli filmlerden yararlanarak bu bağlamda incelenmiştir. Kült filmlerin anaakım değerlere ve konvansiyonel sinema anlayışına olan karşıtlığının karnavalın otoriteye karşı duruşu ve hiyerarşiyi askıya alışı ile örtüştüğü görülmektedir. Kimi durumlarda ise karnaval gibi muhalifliği paketleyip satmalarıyla suçlanabilirler. Kült film hayranları, seyirci olmanın ötesine geçmişlerdir, seyir deneyimleri süresince filmlerle aralarındaki bariyerler yıkılmaya meyillidir. Kült filmlerin insanları bir araya toplayıp, ortak bir aktiviteye katılmalarına vesile olduğu için topluluk duygusu oluşturdukları görülebilir. Bu aktivite zamanının kendine özgü bir atmosfere sahip olduğu ve normal zamanın akışından farklı bir şekilde işlediği iddia edilir. Ayrıca değişkenliğe sahip ve tanımlanması zor bir kavram oluşu, sanat ve sanat-dışı ayrımlarını reddedişi ve ihlal yaratması gibi yapısal ve üslupsal ayrımları incelendiğinde karnavalesk özelliklerle genel olarak benzeştiği ortaya konulmuştur.

Kült filmlerin elbette Bahtinyen karnaval kadar özgürlükçü ve serbest bir ortam yaratmakta başarılı olduğu iddia edilemez. Karnavalın bütün unsurlarını taşıdığı da söylenemez. Karnaval kavramıyla bağdaşmayan kimi özelliklerine çalışma içerisinde değinilmiştir. Kült film kavramında bireyler kendi başlarına önem teşkil ederler. Bahtinyen karnaval gibi herkesi davet eden bir yapıya sahip değildir. Hayranların zaman zaman 'öteki'lerden farklılıklarını vurgulamak için bu filmleri benimsedikleri görülebilir. Dünyayı Kurtaran Adam örneğinde görülebileceği gibi külte dönüşmüş 'ucuz' filmlerin sahiplenilmesi bir sinema kültürü gerektirmektedir. Kült filme dair bu 'kültürel seçkinci' olarak görülebilecek niteliğin karnavalesk yapısına halel getirdiği söylenebilir. Ancak sinemada, ne kadar tartışmalı ve yoruma açık bir kavram olursa olsun, 'kült film' kadar kendi özerk alanını yaratabilmiş, egemen değerlere kafa tutabilen ve egemen anlayış kalıplarını kırabilen metinsel özelliklere sahip; tutkulu seyircileri bir araya toplayabilen ve onlara geçici bir karnavalesk özgürlük sağlayabilen başka bir kapsayıcı kavrama rastlamak pek mümkün değildir.

\section{Kaynakça}

Bahtin, M. (2001). Karnavaldan Romana Edebiyat Teorisinden Dil Felsefesine Seçme Yazılar (Çev. C. Soydemir). İstanbul: Ayrıntı Yayınları.

Bahtin, M. (2005). Rabelais ve Dünyası (Çev. Ç. Öztek). İstanbul: Ayrıntı Yayınları.

Bahtin, M. (2020). Dostoyevski Poetikasının Sorunları (Çev. S. Gürses). İstanbul: Alfa Yayınları. 
Behlil, M. (2001). Bir Türk 'Camp' Klasiği: Bu İkiliye Dikkat. D. Derman, M. Behlil (ed.), Türk Film Araştırmalarında Yeni Yönelimler 1 (ss. 203-210). İstanbul: Bağlam Yayıncılık.

Church, D. (2008). Cult Film: A Critical Symposium. 16 Aralık 2019 tarihinde https://www. cineaste.com/winter2008/cult-film-a-critical-symposium adresinden edinilmiştir.

Corrigan, T. (1991). Film and the Culture of Cult. J. P. Telotte (ed.), The Cult Film Experience: Beyond All Reason (ss. 26-37). Austin, USA: University of Texas Press.

Danow, D.K. (1995). The Spirit of Carnival: Magical Realism and the Grotesque. Kentucky, USA: The University Press of Kentucky.

Eco, U. (2008). Casablanca: Cult movies and intertextual collage. E. Mathijs, X. Mendik (eds.), The Cult Film Reader (ss. 67-75). New York, USA: Open University Press.

Ertan, E. (2007). Kült Filmler 1. Sinema Merkez Dergisi, Sayı: 2007-01, Ücretsiz Ek.

French, K. ve French, P. (1999). Cult Movies. London, UK: Pavilion Books Limited.

Hills, M. (2008). Cult Film: A Critical Symposium. 16 Aralık 2019 tarihinde https://www.cineaste. com/winter2008/cult-film-a-critical-symposium adresinden edinilmiştir.

Hyman, T. ve Malbert, R. (2000). Carnivalesque. London: UK: Hayward Gallery Publishing.

Irzık, S. (2001). Önsöz. M. Bahtin (ed.), Karnavaldan Romana Edebiyat Teorisinden Dil Felsefesine Seçme Yazılar (Çev. C. Soydemir). İstanbul: Ayrıntı Yayınları.

Jancovich, M. (2002). Cult Fictions: Cult Movies, Subcultural Capital and the Production of Cultural Distinctions. Cultural Studies: Theorizing Politics, Politicizing Theory, 16(2), 306-322.

Jancovich, M., Reboll, A.L., Stringer, J., Wills, A. (2003). Defining Cult Movies: The Cultural Politics of Oppositional Taste (Inside Popular Film). Manchester, UK: Manchester University Press.

JerryLiuFilms (2017, 16 Mayıs). Rocky Horror Picture Show Live Show At Nuart Theatre (With Audience Participation) [Video File]. 8 Ocak 2020 tarihinde https://youtu.be/U74EpC9IJno adresinden edinilmiştir.

Lechte, J. (2006). Elli Çağdaş Düşünür Yapısalcılıktan Postmoderniteye (Çev. B. Yıldırım). İstanbul: Açılımkitap.

Marshall, G. (1999). Sosyoloji Sözlüğü (Çev. O. Akınhay, D. Kömürcü). Ankara: Bilim ve Sanat Yayınları.

Mathijs, E. ve Mendik, X. (2008). The Cult Film Reader. New York, USA: Open University Press.

Mathijs, E. (2008). Cult Film: A Critical Symposium. 16 Aralık 2019 tarihinde https://www. cineaste.com/winter2008/cult-film-a-critical-symposium adresinden edinilmiştir.

Morson, G.S. ve Emerson, C. (1990). Mikhail Bakhtin: Creation of a Prosaics. USA: Stanford University Press.

Movie or Bust (2018, 14 Haziran). The Room Audience Reaction (Full) [Video File]. 8 Ocak 2020 tarihinde https://youtu.be/F7gsCYZXVYE adresinden edinilmiştir. 
Mutlu, E. (2005). Globalleşme, Popüler Kültür ve Medya. Ankara: Ütopya Yayınevi.

Sarkhosh, K. ve Menninghaus, W. (2016). Enjoying trash films: Underlying features, viewing stances, and experiential response dimensions. Poetics, 57, 40-54. https://doi.org/10.1016/j. poetic.2016.04.002

Sconce, J. (2008). 'Trashing' the academy: Taste, excess and emerging politics of cinematic style. E. Mathijs, X. Mendik (eds.), The Cult Film Reader (ss. 100-118). New York, USA: Open University Press.

Sexton, J. (2008). Cult Film: A Critical Symposium. 16 Aralık 2019 tarihinde https://www. cineaste.com/winter2008/cult-film-a-critical-symposium adresinden edinilmiştir.

Smith, P. (2005). Kültürel Kuram (Çev. S. Güzelsarı, İ. Gündoğdu). İstanbul: Babil Yayınları.

Stam, R. (1992). Subversive Pleasures: Bakhtin, Cultural Criticism and Film. Baltimore, USA: The Johns Hopkins University Press.

Stam, R. (2000). Film Theory: An Introduction. London, UK: Blackwell Publishing.

Zedd, N. (n.d.). Cinema of Transgression Manifesto. 27 Aralık 2019 tarihinde http://www.ubu. com/film/transgression.html adresinden edinilmiştir. 